\title{
OS NOVOS INTELECTUAIS GANHAM VOZ ATRAVÉS DO CIBERESPAÇO BLOGUEIROS E A ESCRITA DE SI
}

Aline Miranda é escritora, revisora, blogueira e mestranda em Literatura, Cultura e Contemporaneidade pela PUC- Rio. E-mail: alinemiranda.br@gmail.com

Resumo

Este artigo pretende abordar um novo cenário da da internet como forma de criação de identidade, e sobre la importancia de la Internet como forma de de construção de história e memória.

\section{Resumen}

creación de identidad, y construcción de historia y memoria.

Otra vez repito que no soy un crítico imparcial y objetivo. Mis juicios se nutren de mis ideales, de mis sentimientos, de mis pasiones.

\section{José Carlos Mariátegui}

\section{1) Da introdução}

O que um blog pode ser? Quem você quer ser?

"Eu Isadora Faber que tenho 13 anos, estou fazendo essa página sozinha, para mostrar a verdade sobre as escolas públicas. Quero melhor não só pra mim, mas pra todos."

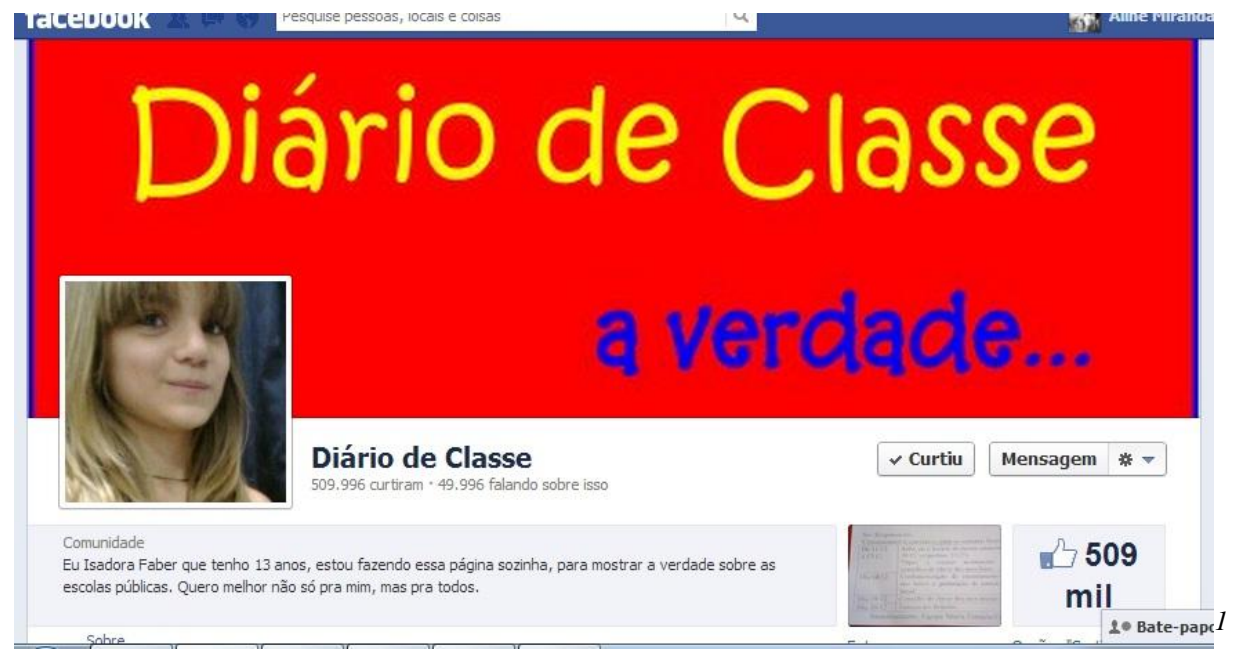


“Cuando empecé a escribir mi blog Generación $Y$, quería sacar a la luz pública muchas frustraciones, quería hacerlo sin violencia verbal, ni con un discurso político, sino a través de un texto moderado, que pudiera influir en las personas que lo leyeran." (SÁNCHEZ, Yoani)

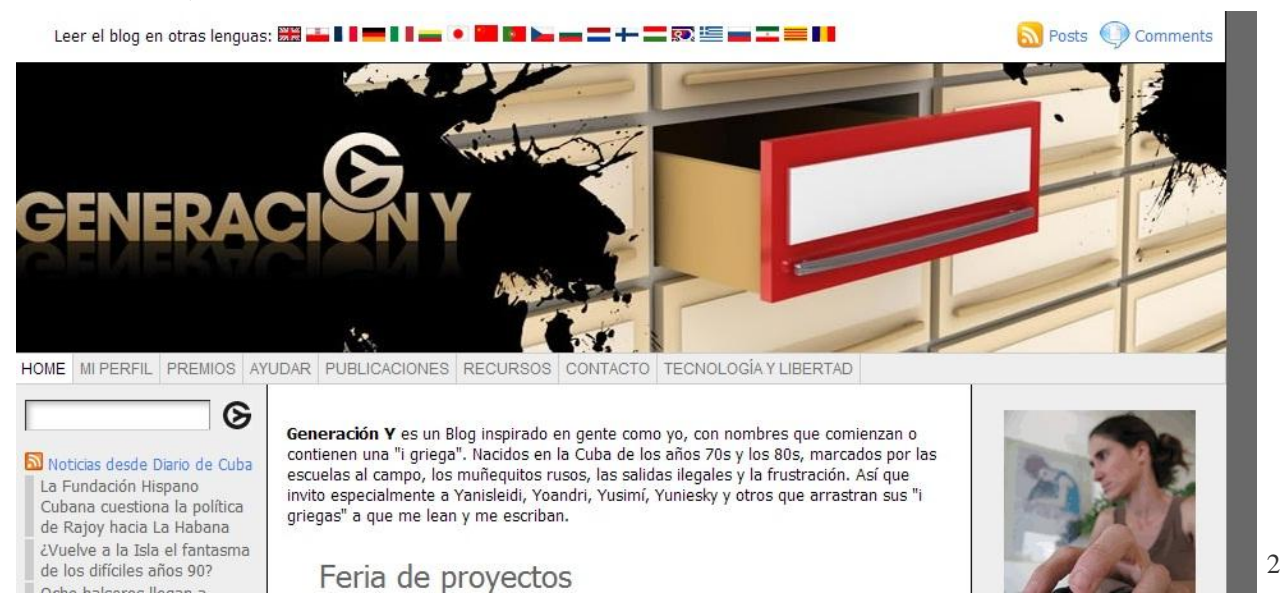

O que pode haver em comum entre uma jovem brasileira e uma mulher cubana? E entre elas e dois chineses? E entre esses e mais tantos outros blogueiros como eu, e como alguns de vocês?

O que há em comum entre eles (ou nós) é que todos se expressam através de um novo cenário de escrita, a internet, que apresenta questões específicas como: quem e o quê legitima no ciberespaço, como e porquê se escreve, quem e como se lê.

Pretendo, neste artigo, abrir uma reflexão sobre a importância e a força da internet como forma de criação de identidade e memória, e escrita de história (de si, do outros, da "nação"). Proponho pensarmos em como a democratização da escrita e a ampliação do acesso à internet permitiu o surgimento de novos autores, e como esse mesmo espaço que dá voz e visibilidade a eles também os deposita num tubo infinito em meio ao excesso de vozes e palavras. Como destacar-se em um espaço tão amplo como a internet? Que ferramentas utilizar para se obter reconhecimento dentro desse meio em que a cada dia surge um novo blog?

\section{2) Da internet como meio}

Comecei minha pesquisa na especialização em Literatura Hispanoamerica na Universidade Federal do Rio de Janeiro com foco no blog da cubana Yoani Sánchez, somando agora a ele outros espaços na internet onde pessoas ditas comuns imprimem suas verdades participando, de alguma forma, da escrita da História. Outro mês, por essas felizes coincidências da vida (uma amiga sempre me diz que não há coincidências) estava em cartaz no Festival de Cinema do Rio um documentário sobre blogueiros chineses. Dois amigos me avisaram do filme por saberem do meu interesse 
pelo tema. Fui. Posso dizer que Yoani e a menina Isadora não estão sozinhas. Não estamos. Nós que fazemos parte dessa massa. E a "massa" não é homogênea.

A internet pode ser um exemplo de um mundo dito "pós-moderno": líquido, fragmentado e em excesso. Se Cortázar descrevia em seu conto "Fim do mundo do fim" o excesso de palavras impressas, hoje se acumulam a essas os textos na rede virtual. Nele, a identidade do autor é questionada, as palavras são apropriadas, recortadas, reformuladas, e a cada nova apropriação um novo nome a identifica, o autor não é mais único, não há a "segurança" de uma edição impressa. Na internet, o sujeito pode ter variadas máscaras, ser "pluridentitário". Uma pessoa pode conversar separadamente, mas de forma simultânea, com vários outros ao mesmo tempo, e de diversos assuntos sem necessária ligação, nos chamados chats ou bate-papos. Seria a fragmentação do ser?

São os simples e anônimos ocupando o espaço antes reservado aos grandes mitos e heróis, através de uma miríade de relatos fragmentados. E os blogs são exemplo desse "deslocamento do ponto de mira onisciente e ordenador em benefício da pluralidade de vozes, da hibridização, da mistura irreverente de cânones, retóricas, paradigmas e estilos", de que fala Leonor Arfuch (2010).

$\mathrm{O}$ mundo informatizado permite a grande circulação de informações - o blog Generación Y, de Yoani Sánchez, que foi criado em abril de 2007 e já ultrapassou a marca de 14 milhões de visitas, tem suas publicações traduzidas para vinte idiomas. Isso gera longo alcance para a propagação de ideias e opiniões e para a busca por mudanças na vida pública e política, transformando a anônima cubana em um sujeito da história. A opinião contida no blog não é apenas de Sánchez, mas de todos que visitam e comentam frequentemente em seu espaço na internet, toda a comunidade de opinião que se cria ao redor de seus textos, formando um intercâmbio intelectual entre indivíduos e cidadãos. O blog de Sánchez inspirou diversos outros cubanos a criarem seus espaços na internet.

Yoani é (ou era) o cidadão anônimo com sua voz oriunda de um ambiente privado, até pouco tempo marcado como feminino, o espaço doméstico. Já a brasileira Isadora Faber utiliza uma página, que ela intitulou de "Diário de Classe: a verdade...", na rede social Facebook, para registrar as más condições da Escola Municipal Maria Tomázia Coelho em que ela e seus colegas estudam na rede pública de Florianópolis, Santa Catarina. Quase diariamente a aluna publica textos e fotos de ambientes que precisam de reparos, imagens da merenda servida, e relata a falta de professores e tantas outras escassezes. Ainda que menor de idade, Isadora recebeu críticas e ameaças, encontrando maior segurança ao receber apoio da secretária de educação de Florianópolis e da mídia, que passou a divulgá-la, proporcionando, inclusive, seu encontro com a escocesa Martha Payne, de 9 anos, ${ }^{3}$ que mantém um blog com fotos diárias da comida servida em sua escola, acompanhadas de suas observações e reclamações. Ambas conseguiram melhorias em seus colégios. 
Segue abaixo um trecho da página de Isadora (imagem obtida através da ferramenta print screen) em que se vemos uma fotografia, feita pela mesma, de parte da quadra de esportes da escola, seguida de um comentário escrito. Além disso há um vídeo em comemoração às então 500 mil “curtidas" de sua página, que seria o equivalente ao número de fãs da página. Na filmagem a jovem agradece a todos que apoiam sua causa: "educação de qualidade", em suas palavras.

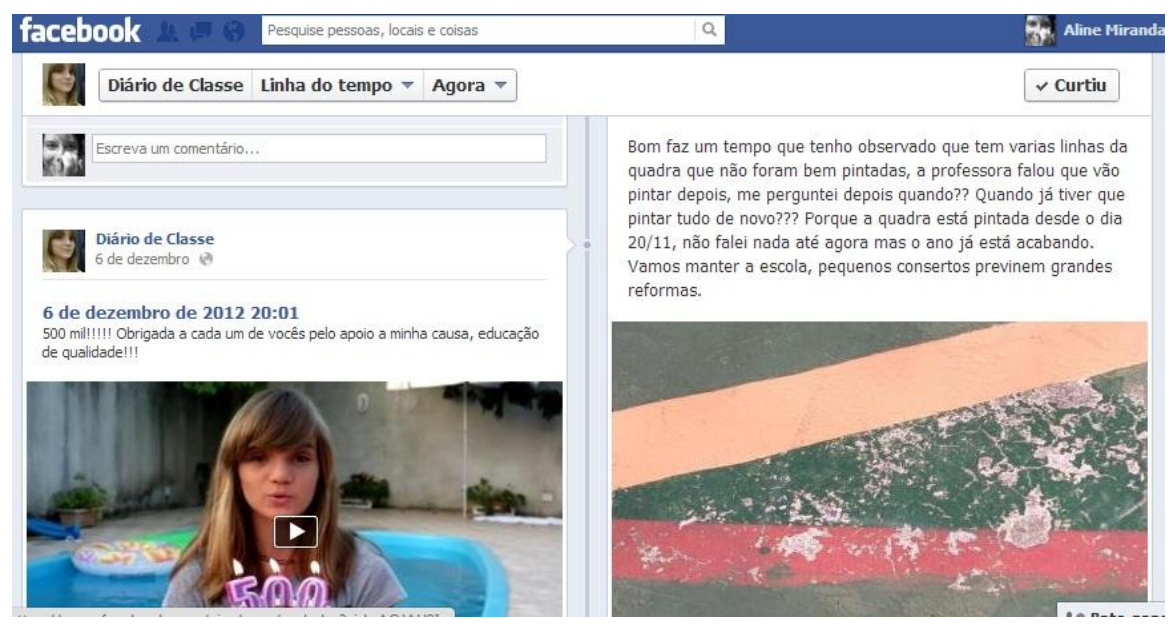

Os blogs podem ser utilizados pelos então inaudíveis cidadãos "comuns" como espaço de voz e visibilidade gerando, através de suas palavras, discursos políticos. Como outro exemplo há os "personagens" retratados no documentário "Blogueiros da China" (High tech, low life, no original) de Stephen Maing, os chineses Zola, de 26 anos e Tiger Temple, de 57 anos. Ambos partilham de algumas dificuldades semelhantes às que Yoani diz enfrentar, por "atuarem" em países onde a liberdade de expressão é um tema delicado e a "verdade oficial" é por vezes questionada.

Esses "novos intelectuais" já se inserem no cotidiano, utilizando de um meio de comunicação de massa - que por vezes é visto apenas como mero entretenimento - para interferir politicamente, trazendo visibilidade para as questões que apontam e conseguindo, com o alcance de suas palavras, mudanças na realidade social em que vivem. Que lugar político ocupa o blog de Yoani que não tem explicitamente pretensões "artísticas" ou de seguir uma carreira política convencional?

Yoani e Isadora escrevem a partir de suas casas sobre o que veem, vivem, e opinam também sobre fatos que acontecem em sua cidade, seu estado, seu país, seu mundo. A escrita na internet ultrapassa a aldeia. Na rede virtual a aldeia torna-se global. Qual a diferença entre ser ouvido pelo seu vizinho e ser escutado por todo o mundo?

Os blogueiros chineses vão atrás da notícia. Circulam pelo país com seus equipamentos procurando cobrir fatos que a mídia oficial camufla ou simplesmente não divulga. Tiger, que viaja de bicicleta, ficou conhecido como o primeiro "repórtercidadão" da China, mas faz questão de dizer que não é um jornalista, não é um 
"profissional". Essa nomenclatura "cidadão" me faz lembrar a tal lei da educação brasileira que se afirma voltada para o desenvolvimento do aluno como um cidadão ativo e crítico. Seria agora a internet um espaço possível para a atuação desses cidadãos "engajados"? Em comum esse blogueiros têm o desejo de que suas vozes sejam unidas à voz oficial na construção da história do país. Uma história sendo escrita no presente, com todas as suas versões, criando a memória histórica dos comuns.

Yoani, por exemplo, começou a ter a consciência da divisão entre os cubanos durante sua infância. Presenciou o episódio de Muriel quando uma multidão de 10 mil pessoas se instalou na embaixada peruana em Havana, exigindo a autorização para deixarem Cuba. O governo acabou cedendo e permitindo, mas muitos não conseguiram chegar à outra margem com suas precárias embarcações. O conto "Termina el desfile", de Reinaldo Arenas, escritor também cubano, relata esse acontecimento. Yoani, em seu livro ${ }^{4}$, também:

Na minha escola primária, nos contavam que eles tinham ido até a outra margem para buscar drogas e perversões. Era assim que eu os imaginava, em uma eterna festa de álcool e risadas a noventa milhas de distância. (...) Não acredito que voltaremos a ter novos acontecimentos como os do porto de Muriel. A emigração ocorre agora de forma mais calada nas rochosas enseadas por onde - a cada madrugada - alguém se lança ao mar e nos consulados abarrotados de gente em busca de um visto. (SÁNCHEZ, 2009)

Podemos notar nesse trecho a lembrança, que não temos como afirmar se é "verdadeira" ou não, de um fato ocorrido narrado através de um só olhar. É o chamado "perigo da história única"- termo usado por Chimamanda Adichie, escritora nigeriana, para exemplificar a dificuldade da busca de uma voz sua dentro das histórias eurocêntricas que lhe foram contadas durante toda a vida. Para a menina Yoani, a verdade única estava no que ouvia na escola. A importância do acesso a outros olhares para um mesmo fato está na possibilidade de escolher, selecionar, recortar e juntar, construindo seu próprio discurso, sendo agente de sua própria história.

\section{3) Das linguagens de si nos blogs}

Os blogs são um modo diferente de fixação da escrita, um território transitório constante. A cada clique, o leitor embarca para novos espaços, numa viagem infinita em que muitas vezes se perde ou se esquece o ponto de partida. De que maneira esse suporte interfere na escrita? E na recepção? A internet oferece essa possibilidade de propagação de ideias, de palavras. Teoricamente "qualquer" pessoa pode criar seu objeto e fazer seu produto circular. Mas, da mesma maneira, e talvez por isso, a rede virtual é como um labirinto em que vozes se misturam, se entrelaçam e se sobrepõem, fazendo com que uma voz possa, sim, dizer, mas para ouvidos surdos. Você diz. Mas quem escuta? 
O fenômeno do "falar de si" já não é raridade nas livrarias, devido, por parte, ao "avanço da midiatização" de que fala Arfuch, que fez com que "a palavra biográfíca íntima, privada, longe de se circunscrever aos diários secretos, cartas (...), estivesse disponível, até a saturação, em formatos e suportes de escala global.” (ARFUCH, 2010) Os blogs nasceram a princípio como uma ferramenta de diário virtual, com possibilidades que permitiam, inclusive, deixá-lo "invisível” para outros internautas. Com o tempo, estes espaços abarcaram finalidades inúmeras além da função de "diário não-secreto", e o espaço das escritas de si invadiu também sites de revistas, de "celebridades", e até outras redes sociais, como o twitter e o facebook. Klinger (2007) também aponta, citando Arfuch, o "avanço da cultura midiática de fim de século" como fator que proporciona a produção de "uma crescente visibilidade do privado, uma espetacularização da intimidade" onde podemos notar o "sucesso mercadológico das memórias, das biografias, das autobiografias e dos testemunhos" e também "o surto dos blogs na internet".

Yoani tem consciência dessa flexibilidade entre o público e o privado que sua escrita provoca em sua vida (e sua vida em sua escrita), mas diz que sua perda de privacidade de "anos de silêncio, intimidade e reserva" é o que evita que ela "seja devorada pela engrenagem que já engoliu a tantos". Segundo ela, as paredes de sua vida se tornaram mais transparentes, mas quem lê seus escritos a protege.

Os textos dos blogueiros citados são muito semelhantes às crônicas, com doses de informação jornalística e análise crítica da realidade, mas também semelhantes aos diários, com escrita em primeira pessoa, relatos cotidianos, impressões e possível lirismo. São híbridos de manifesto político e auto-ficção. Uma vida inventada? Nem sempre é possível saber. "A intimidade era teatro", disse Ana Cristina César (Crítica e Tradução).

Abaixo segue um exemplo de um blog com escrita "poético-recordativa". Criei esse termo (aceito sugestões) para tentar exemplificar. Mas o texto fala por si. É de uma aluna do mesmo curso de mestrado que faço, e minha amiga desde os 17 anos, quando ainda morávamos em Cabo Frio. Joana Rabelo é professora de artes, atriz, e escreve poesias ao mesmo tempo fortes e doces: 


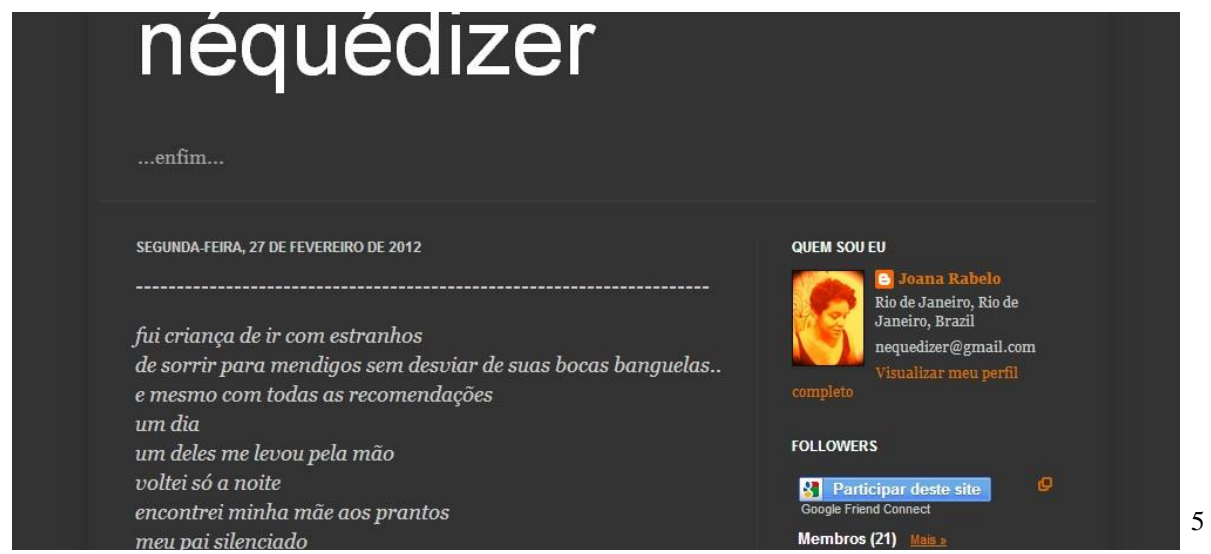

A "escrita de si" sempre me intrigou. Escrevi alguns diários durante a vida (que na adolescência passam a ser chamados de agenda, em tentativa de evitar parecer infantil, creio). E escrevo em blog. Blogs. Desde maio de 2007 mantenho um. E no primeiro semestre de 2012, enquanto escrevia os trabalhos finais das disciplinas do mestrado, criei outro, para desaguar minhas palavras que não cabiam no texto acadêmico. Para diferenciá-lo de meu blog, digamos mais "literário", escancarei-me em seu título: Diário de uma escritora preguiçosa. Não busco mudar minha realidade social, apesar de fazer críticas às vezes, tão pouco quero escrever a História, apesar de escrever a minha. Meu objetivo talvez seja dar espaço aos pensamentos, dialogar com as pessoas, não sentir-me sozinha e sim, criar memória. Não me lembro de fatos da minha infância. Acho minha memória fraca. (Durante o período de vestibular tomei um remédio natural chamado "Memoriol". Ativação de funções cerebrais em cápsulas.) Por isso escrevo. Para partilhar-me e escrever minha própria vida. Pelo caminho encontrei outros blogs assim, que aprecem caminhar comigo entre a poesia e a recordação. Assim como alguns livros mais "íntimos" (ou não) que sempre me interessaram: os "Outros escritos" da Clarice mãe, estudante, jornalista e tantas outras; o inspirador "Roland Barthes por Roland Barthes"; o "Round I" do Cortázar virginiano como eu, tão cheio de tudo; o "Escrever", de Marguerite Duras, e toda a Ana Cristina César.

Segue exemplo de um dos meus blogs, com um tom próximo ao mesmo tempo do diário e da carta. Foi escrito durante uma viagem: 


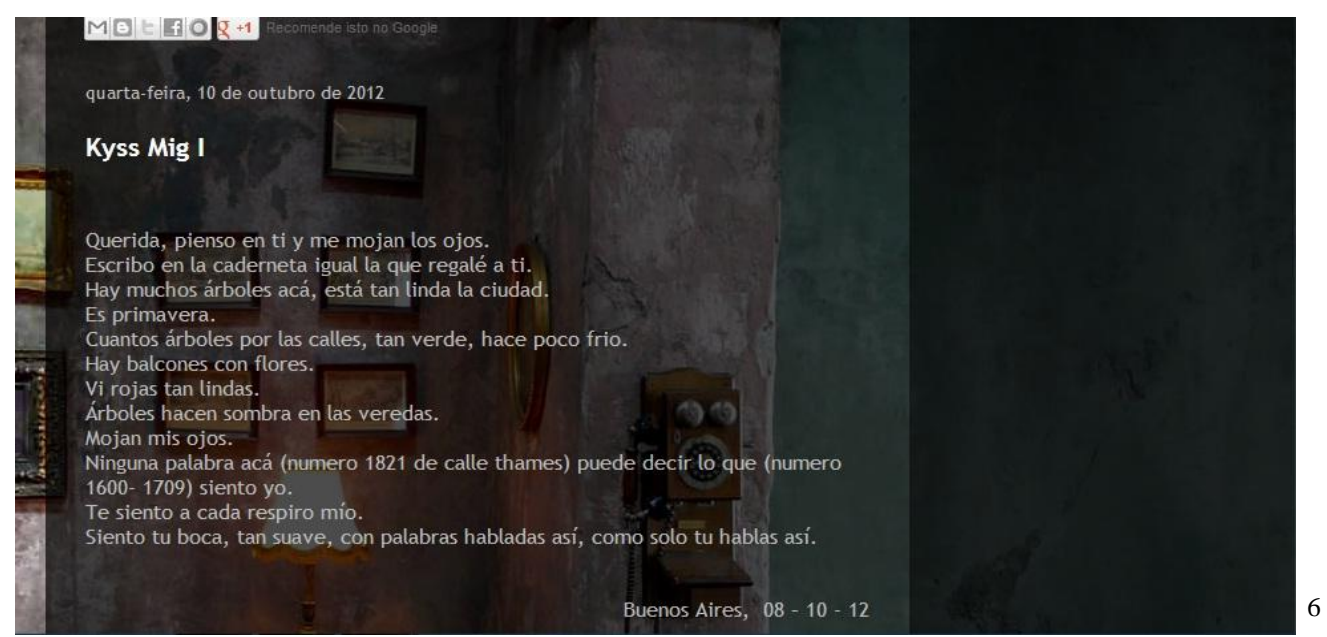

Podemos observar, dentro desses discursos pessoais, objetivos e políticos, alguns pares como voz e silêncio, anonimato e íntimo, memória e crônica. Os espaços já citados estão permeados de textos costurados em linha dupla. A internet que proporciona a possibilidade do anonimato é utilizada para escancarar a intimidade. Abre-se a janela para um (forjado ou não) mundo privado.

A escrita de Yoani é mais permeada de memória e comentários de fatos atuais, como uma tentativa de resgatar sua versão do passado e ser mais uma a escrever a História através de sua história pessoal. A arte cada vez mais se aproxima, se mistura à vida, trazendo fragmentos vitais, os anônimos.

Abaixo mostro outro exemplo de blog com tom poético-recordativo. Esse texto dialoga bastante com o da Joana já citado, por parecer uma tentativa de fixar uma memória passada. No caso delas, memória da infância. A autora desse blog, Letícia Novaes, é cantora e compositora da banda Letuce, e, possivelmente seu texto busca uma identificação entre a pequena e a grande Letícia. Talvez até uma "fabulação":

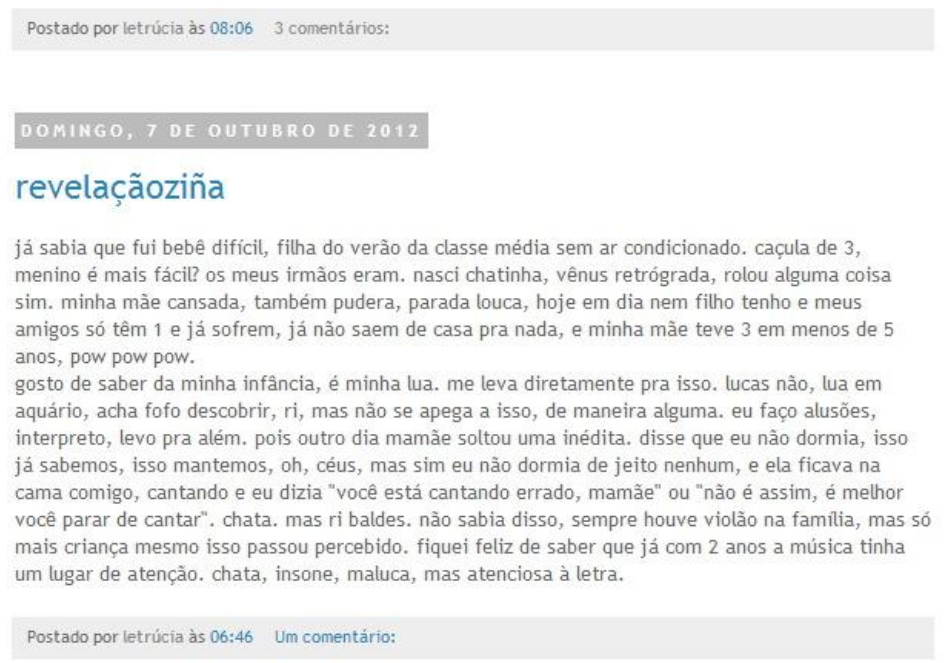


A internet é um novo espaço de circulação entre leitores e escritores, permitindo um diálogo mais direto e possível para um leitor de blog, diferente do que acontecia com o leitor de crônicas de jornal, por exemplo. Nos blogs, a troca pode ser imediata, bastando apenas que o blogueiro e o leitor estejam "conectados" no mesmo instante. Segundo Ana Cláudia Viegas (2006:223), a emergência da memória é "uma das preocupações culturais e políticas centrais das sociedades ocidentais", e as "novas tecnologias da informação e as políticas midiáticas alteram as relações entre memória e esquecimento". Há o medo do esquecimento.

Um exemplo de diálogo entre blogueiro e leitor está nessa postagem do blog da também atriz Patrícia del Rey, soteropolitana moradora de Brasília, que reproduzo como em seu site, abaixo:

\section{"SEXTA-FEIRA, ABRIL 30, 2010}

Poderia morrer essa madrugada, estraçalhada no concreto. Ou submersa no Lago Paranoá. Virar comida de peixe, lenda urbana, pedaços de seca. Conseguir me espalhar por todos os monumentos brancos, dores pingadas de um lamento. Rabiscar essa espera infinita e fazer um quadro abstrato com cores frias. Não passar pelo caminho da tua casa, não sentir a lembrança estampada no meu rosto marcado. Ser um pequeno azulejo quebrado do parque da cidade. E cessar qualquer esperança chula de uma felicidade mofada.

1 comentário. Cineasta 81 disse: Que deprimente. ${ }^{8}$

No blog há a possibilidade desse diálogo direto entre quem escreve e quem lê, o leitor participa da construção do texto, podendo comentar, sugerir e criticar. O texto na internet pode assim ser infinito, interminável. Ao lançar o livro com alguns de seus posts, Patrícia incluiu também diversos comentários justificando que faziam parte da escrita de seu blog.

E dentre tantas, outras perguntas que surgem ao estudar blogs é: enquanto o texto está na internet Yoani é considerada blogueira. Redigir um livro com um apanhado de seus textos do blog a fará ganhar o "status" de escritora? Não seriam os blogueiros de certa forma autores também, se também se utilizam da escrita como expressão?

$\mathrm{Na}$ internet a identidade do autor é frequentemente questionada. Quantas vezes nós mesmo recebemos e encaminhamos emails com belos textos de Luis Fernando Veríssimo, Clarice Lispector, Caio Fernando Abreu ou Arnaldo Jabor, que em verdade nunca os escreveram? As palavras são apropriadas, recortadas, reformuladas, e a cada nova apropriação um novo nome a identifica, o autor não é mais único, não há a "segurança" de uma edição impressa.

Patrícia, no prefácio de seu livro, comenta essa relação blog-livro:

Um blog é frágil. Agrega covardia também. Basta clicar no botão, e extermino todas as partes. Viro lembrança, página não encontrada. Eu apago a poeta que existia ali. 
Assumir um livro é outro passo. É estar na prateleira, etiquetada, embalada pra presente. É se por à prova. Tatuar letras permanentes. Imprimir uma parte de si. A parte escolhida. Marcar o tempo que passou. É ser palavra sem prazo de validade. (DEL Rey, 2011)

Também quero me tatuar "ad aeternum". Mas tenho pavor de agulha. Que seja através de um livro então. Participo de um blog, o TremaLiteratura ${ }^{9}$, em que catorze colunistas se revezam quinzenalmente na escrita de textos. Há o projeto, já em andamento, da publicação de um livro com uma coletânea de nossas postagens. É diferente estar na web e estar na prateleira. Leio bastante na internet, mas gosto muito do objeto livro. E não há oposição estre esses dois espaços. Complementam-se. O blog reatualiza o livro. Como indica a primeira página do livro de Patrícia: "Quer comentar? O livro continua sendo escrito virtualmente. Basta acessar o blog e adicionar seus comentários na postagem escolhida” (DEL Rey, 2011)

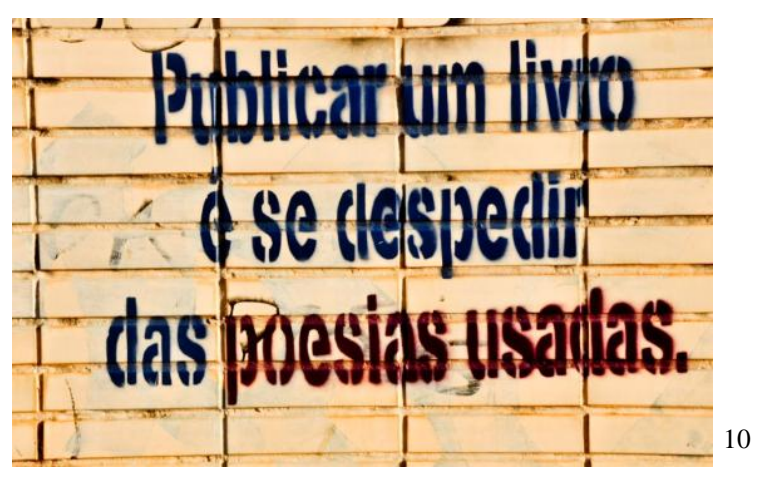

Além disso, quem detém o poder de escrever a Verdade? O que querem apagar da História e o que ressaltar? Se não é a população quem escreve a história de onde vive, como saber se há manipulação? A cada novo relato desses exemplos vemos outras verdades emergirem, unindo-se à superfície da verdade oficial. Ainda assim, continuamos vivendo sob poder. Do Estado e/ou de blocos midiáticos muito "dominadores". Esses blogueiros utilizam de "armas" afetivo-intelectuais, não se calam, fazem críticas, comentários, poesia, mesclando razão e sentidos. E presenciamos os grandes heróis e personagens dando espaço aos simples e anônimos indivíduos com uma miríade de relatos fragmentados.

\section{4) Das considerações (ainda não) finais}


O objetivo desse estudo é promover o início de um pensamento sobre os novos intelectuais oriundos dos blogs e de outros espaços da internet, investigando se a rede virtual é um possível espaço para a atuação de cidadãos ditos "engajados". Espero também que esse texto possa proporcionar o pensamento e o debate sobre essas questões tão urgentes, seja por meio de estudos teóricos e de conversas, seja estimulando o desenvolvimento de meios de incentivo à escrita como voz, à palavra como ferramenta.

\section{Post-Scriptum 1:}

Reproduzo aqui a repercussão da foto por mim postada em minha página do facebook após minha apresentação (versão enxuta deste trabalho) realizada no Seminário Letras Expandidas, na PUC-Rio no emblemático dia 12/12/12:

“Aline Miranda compartillhou a foto de Letras Expandidas: a Escrita Para Além Da Literatura. 13 de dezembro.

Joana Rabelo, te trouxe à luz:

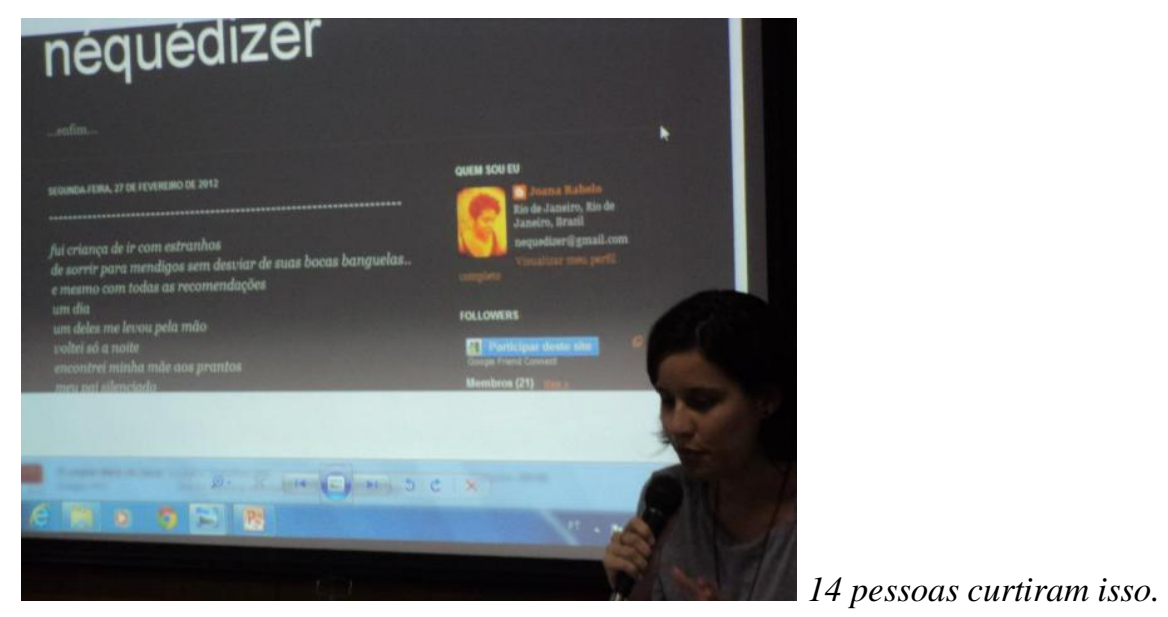

Letícia Novaes: que engraçado ver um blog grande

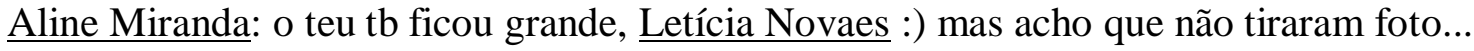
mas riram quando te li, rs.

Letícia Novaes: rá. pq? era engraçado? 
Aline Miranda: minha fala foi toda cheia de "gracinhas", pra não ficar na chatice de texto lido mesmo.

e vc não lembra o que escreveu? tem até onomatopeias: "três filhos seguidos: pow pow pow" haha

Letícia Novaes: eu lembro, queria saber exatamente do que riram. ok. ONOMATOPEIAS.

Aline Miranda: ps: gravaram, depois vc vê o vídeo, Letícia, e vê as partes "risíveis". (se eu aprovar a divulgação, claro. haha)

Patrícia Del Rey: Linda. =]

\section{Post-Scriptum 2:}

Após a apresentação do trabalho no seminário continuei pesquisando outros espaços na internet e descobri, há pouquíssimo tempo, um blog ("do seu pai”) que parece ter nascido já para ser publicado em livro, tamanha é sua qualidade e "profissionalismo". Além disso, é explicitamente um espaço para armazenamento de memória para o futuro. Um pai escreve (e registra em lindas fotos) momentos de seus filhos para que os mesmos possam depois. Na página inicial do site há a explicação da criação do espaço:

No dia 29 de janeiro de 2013, pensei em escrever um livro de histórias infantis. O livro, este blog. As histórias, reais. E os infantis são meus filhos, João e Irene (tudo bem, às vezes também entro na categoria infantil). Mas isso já seria um outro blog, uma outra história. Seja bem-vindo. Esse aqui é um blog de pai para filhos. Com todo o amor que tenho dentro e fora de mim. (PEDRO, 2013)

Há um bom número de blogs dedicados à escrita de acontecimentos e opiniões para serem lidos algum tempo depois. É o caso de outros sites como o "Para Francisco" e o "Cartas ao meu bebê", de uma amiga formada em Letras, Mariáh Oyarzabal. Ambos de mães para seus filhos. O primeiro já "virou" livro. O segundo engatinha no mesmo caminho. Esses pais e mães poderiam escrever os detalhes preciosos do cotidiano e do desenvolvimento de seus filhos em algum caderno, ou guardar folhas impressas em pastas, ou ainda salvar os arquivos digitados em pen drive ou e-mail. Mas escolheram compartilhar suas histórias em ciberespaços, publicamente. Pedro, o pai, em seu último texto (ou carta-poema) direcionado à bebê Irene, escreve sobre os dois (ou mais?) lados da internet. Deixo-lhes com essas palavras, recomendando a leitura desses tantos blogs citados. Inclusive o meu.

Um abraço, 
Aline.

www.outrasbagatelas.blogspot.com

Madrugada de outono no Rio.

São Paulo, 11 de abril de 2013.

Irene,

a internet nos afasta.

Nos faz ficar cabisbaixos, mais preocupados

com o sms enviado, o whatsapp recebido

e o doubletap distribuído no Instagram

(sério, busca isso, você vai se divertir

com essa rede social da minha época).

Nos tornamos ausentes.

Vamos a festas, shows, bares,

exposições e encontros, mas deixamos

de conviver com os amigos,

pois estamos sempre conectados,

digitando, postando, tirando o nosso

espírito dos locais físicos e nos transportando

para um universo digital paralelo

perverso, frio, desumano.

Como tudo parece estar interligado,

ficamos, então, mergulhados neste

imenso vazio junto com muitas e muitas

outras pessoas - mas sem vê-las,

tocá-las, acariciá-las.

O futuro amedronta, filha.

Pode ser que as relações humanas

sejam todas abaladas por isso e, assim,

você e o seu irmão recebam isso

de herança da partícula de Humanidade

que corresponde à minha geração.

Que absurdo, né, filha?

Sabia que tem gente que pensa

exatamente assim?

Eu não penso.

Estou convicto de que tudo isso

aqui tem nos aproximado mais e mais

daquilo que realmente interessa.

Sinto isso na pele. Sinto isso no coração.

Sinto muito pelos que não usam

a internet a favor das relações sólidas. 
Do seu pai,

Pedro. ${ }^{11}$

\footnotetext{
${ }^{1}$ Imagem. Disponível em https://www.facebook.com/DiariodeClasseSC?ref=ts\&fref=ts Acesso em setembro de 2012.

${ }^{2}$ Imagem. Disponível em http://www.desdecuba.com/generaciony/ Acesso em setembro de 2012.

${ }^{3}$ http://www.bbc.co.uk/portuguese/videos_e_fotos/2012/09/120901_blogueiras_mirins_jp.shtml

${ }^{4}$ O livro De Cuba com carinho é a seleção, feita pela autora, de alguns textos publicados em seu blog Generación $Y$.

${ }^{5}$ Leia o texto completo em: http://nequedizer.blogspot.com.br/2011/05/blog-post_8474.html Acesso em setembro de 2012.

6 Imagem. Disponível em http://diariodeumaescritorapreguicosa.blogspot.com.br/2012/10/kyss-migi.html Acesso em setembro de 2012.

7 Imagem. Disponível em http://donzelice.blogspot.com.br/2012/10/revelacaozina.html Acesso em setembro de 2012.

${ }^{8}$ Disponível em http://entreaberta.blogspot.com.br/2010_04_01_archive.html ou no livro de mesmo nome com seleção de textos do blog feito pela autora, p.73

${ }^{9}$ TREMALITERATURA. Disponível em http://tremaliteratura.com/ Acesso em abril de 2013.

${ }^{10}$ Fotografia do Coletivo Transverso, do qual Patrícia faz parte, presente em seu livro.

${ }^{11}$ DO SEU PAI. Disponível em http://www.doseupai.com/\#!18/c166e Acesso em abril de 2013.
}

\section{Referências Bibliográficas}

ARFUCH, Leonor: O espaço biográfico: dilemas da subjetividade contemporânea. Trad. Paloma Vidal. Rio de Janeiro: EdUerj, 2010.

CORTÁZAR, Julio. Fim do mundo do fim. In: Histórias de cronópios e de famas. Trad. Gloria Rodríguez. 13a . ed. Rio de Janeiro: Civilização Brasileira, 2011. p.66-68.

DEL Rey, Patrícia. Entreaberta: (sf.) ato de entreabrir; descobrimento do céu em um dia enevoado. Brasília, 2011.

KLINGER, Diana. Esritas de si - o retorno do autor. In: Escritas de si, escritas do outro. Rio de Janeiro: 7Letras, 2007, p. 19-62.

SÁNCHEZ, Yoani. De Cuba, com carinho. Trad. Benivaldo Araújo e Carlos Petrolini Jr. São Paulo: Contexto, 2009.

VIEGAS, Ana Cláudia. A ficção brasileira contemporânea e as redes hipertextuais. In: Revista Brasileira de Literatura Comparada. 2006.

Sites: 
CARTAS AO MEU BEBÊ. Disponível em http://cartasaomeubebe.com Acesso em 2013.

DESDE CUBA. Disponível em http://desdecuba.com/generaciony Acesso em 2013.

DIÁRIO DE UMA ESCRITORA PREGUIÇOSA. Disponível em http://diariodeumaescritorapreguicosa.blogspot.com.br Acesso em 2013.

DONZELICE. Disponível em http://donzelice.blogspot.com.br Acesso em 2013.

DO SEU PAI. Disponível em http://doseupai.com Acesso em 2013.

ENTREABERTA. Disponível em http://entreaberta.blogspot.com.br Acesso em 2013.

NÉ QUÉ DIZER. Disponível em http://nequedizer.blogspot.com.br Acesso em 2013.

PARA FRANCISCO. Disponível em http://parafrancisco.blogspot.com.br Acesso em 2013. 